\title{
BROWNIES BEBAS GLUTEN DARI TEPUNG KORO PEDANG (Canavalia ensiformis $L$ ) DENGAN SUBSTITUSI TEPUNG MOCAF DAN VARIASI LAMA PEMANGGANGAN
}

\author{
GLUTEN FREE BROWNIES FROM JACK BEAN FLOUR (Canavalia ensiformis L) WITH \\ SUBSTITUTION OF MOCAF FLOUR AND VARIATION OF BAKING TIME
}

\author{
Tri Nikawati, Yannie Asrie Widanti, Akhmad Mustofa \\ Fakultas Teknologi Dan Industri Pangan Universitas Slamet Riyadi Surakarta, \\ JL. Sumpah Pemuda 18 Joglo Kadipiro Surakarta 57316 \\ Email: asrie.yannie2@gmail.com
}

Diserahkan [30 November 2019]; Diterima [20 Januari 2020]; Dipublikasi [21 Februari 2020]

\begin{abstract}
Brownies are cakes made from four basic ingredients, namely flour, fat, sugar and eggs. Brownies made in this study differ from brownies in general, namely the use of row canavalia ensiformis flour and mocaf flour. Canavalia ensiformis flour is rich in protein and mocaf flour which has characteristics such as flour. This study used a completely randomized design (CRD) consisting of 2 factors. The first factor is the comparison canavalia ensiformis flour and mocaf flour and the second factor is the length of the period and each factor has 3 treatments resulting in 9 different treatments. The best results showed that the combination of the concentration of canavalia ensiformis and mocaf flour and roasting time of 30:60 60 minutes was based on the best and best organolaptic protein clams. In this treatment, water content was $19.01 \%$, ash content was $9.19 \%$, fat content was $22.34 \%$, total sugar content was $18.04 \%$, protein content was $8.73 \%$. And organolaptic test on brown color 2.95, canavalia ensiformis taste 3.13, mocaf taste 3.21, soft texture 2.80 and overall preference 3.11 preferred.
\end{abstract}

Keywords : Brownies, canavalia ensiformis l, flour, long time consuming, substitution

\section{ABSTRAK}

Brownies merupakan cake yang terbuat dari empat bahan dasar yaitu tepung, lemak, gula dan telur. Brownies yang dibuat pada penelitian ini berbeda dari brownies pada umumnya, yaitu penggunaan bahan baku tepung koro pedang dan tepung mocaf. Tepung koro pedang merupakan tepung yang kaya akan proteinya dan tepung mocaf yang mempunyai karaktaristik seperti terigu. Penelitian ini menggunakan rancangan acak lengkap (RAL) yang terdiri 2 faktor. Faktor pertama yaitu perbandingan tepung koro pedang dan tepung mocaf dan fakto kedua lama pemanganggan, masing-masing faktor ada 3 perlakuan sehingga menghasilkan 9 perlakuan yang berbeda. Kombinasi perlakuan perbandingan konsentrasi tepung koro dan tepung mocaf 30:70 dan lama pemanggangan 60 menit adalah hasil terbaik karena memiliki protein yang lebih tinggi. Kombinasi perlakuan ini menghasilkan kadar air 19,01\%, kadar abu 0,18\%, kadar lemak 22,34\%, kadar gula total 18,04\%, kadar protein $8,73 \%$. Serta uji sensoris terhadap warna coklat 2,95, rasa koro pedang 3,13, rasa mocaf 3,21, tektur lembut 2.80 dan kesukaan keseluruhan 3,11 disukai.

Kata kunci : Brownies, koro pedang, mocaf, lama pemanganggan, subtitusi.

\section{PENDAHULUAN}

Indonesia merupakan negara agraris bukan penghasil gandum, sehingga kebutuhan gandum dipenuhi dengan cara impor dari Amerika (11\%), Kanada (14,9\%), dan Australia (70,7\%). Indonesia mengalami kenaikan impor gandum pada tahum 2011, kenaikan gandum hingga 6,2 juta ton (Tempo, 2013).

Di sisi lain indonesia memiliki potensi pangan lokal dari berbagai jenis tanaman yang dapat dimanfaatkan sabagai bahan pangan, di antaranya koro pedang yang diolah menjadi tepung koro pedang dan singkong yang diolah menjadi tepung mocaf. Pemanfaatan koro pedang belum begitu besar, hal ini dikarenakan koro pedang sulit untuk dikupas karena kulit koro pedang cukup keras. Selain itu koro pedang juga mengandung senyawa toksik yaitu asam sianida atau HCN. Akumulasi asam sianida pada tubuh dapat mengakibatkan gangguan yaitu menghambat penyerapan protein dan iodium (Pambayun dan martini, 2000). Kadar sianida atau HCN dapat dihilangkan dengan cara perendaman dan blancing, perendaman ini dapat menurunkan kadar sianida dalam koro pedang hingga $79,7 \%$. Selain itu sianida juga mudah larut dalam air, perlakuan 
perendaman dapat menurunkan kadar sianida pada kacang-kacangan (Kasmidjo, 1990).

Tepung koro pedang termasuk tepung kaya protein karena kandungan protein yang cukup besar yaitu sekitar 37\%. Sifat tepung tepung kaya protein memiliki sifat fungsional yang baik untuk diaplikasikan pada produk pangan olahan seperti sosis, cake, cookies dan nugget menurut Windrati, Nalf, \& Agustine (2010).

Pengembangan tepung mocaf (Modified Cassava Flour) dapat memberikan harapan baru dari ketergantungan kepada tepung terigu. Selain dapat diproduksi dari hasil pertanian lokal, penggunaan tepung mocaf juga memiliki banyak keunggulan dibandingankan dengan tepung terigu. Pada tepung mocaf tidak ada protein gluten yang seringkali harus dihindari oleh orang-orang tertentu yang memiliki alergi atau penyakit yang harus menghindari makananan yang berbau gluten seperti anak autis yang tidak boleh terlalu banyak memakan makanan yang banyak mengandung gluten (Salim, 2011)

Brownies coklat adalah sebuah produk makanan yang dipanggang berbentuk persegi, datar atau bar yang mulai dikembangkan di Amerika Serikat pada akhir abad ke-19 dan dipopulerkan di Amerika Serikat dan Kanada. Saat ini brownies juga menjadi salah satu makanan populer di Indonesia (Widanti \& Mustofa, 2015)

Brownies telah menjadi makanan yang sangat digemari oleh banyak orang, baik dari kalangan anak-anak sampai orang tua. Penelitian ini menggunakan tepung koro dan tepung mocaf untuk mengembangkan produk makanan yang bebas gluten sehingga sehat untuk dikonsumsi terutama untuk orangorang tertentu yang harus menghindari gluten. Pengembangan produk brownies tepung koro yang dimodifikasi dengan tepung mocaf ini juga menambah nilai ekonomis koro pedang dan singkong yang semula jarang dimanfaatkan dalam proses pengolahan bahan pangan.

Selain bebas dari gluten, koro pedang dan singkong juga mudah didapatkan di pasar-pasar atau dari petani sehingga dapat digunakan sebagai bahan baku pengolahan tepung dan brownies. Di dalam penelitian ini tepung biji koro pedang dan tepung mocaf diolah menjadi produk brownies dengan variasi perbandingan tepung dan lama pemanggangan.

Pada penelitian ini bertujuan Menentukan karakteristik kimia, fisik, organoleptik dan menentukan lama pemanggangan brownies mocaf dan tepung koro pedang yang disukai oleh konsumen. Menentukan formulasi brownies yang memiliki protein tinggi dan disukai konsumen.

\section{METODE PENELITIAN}

\section{Bahan}

Bahan - bahan utama yang digunakan dalam penelitian ini adalah tepung koro, tepung mocaf merk fuko, margarin merk blue band, telur, coklat bubuk merk p3, coklat blok merk virgo, gula mek gulaku, baking powder dan bahan untuk analisis kimia biokimia Aquades, Petroleum ether, Glukosa anhidrat, Reagensia arsenomolhidat, Reagenia nelson dan sensoris lainnya.

\section{Alat}

Alat yang digunakan dalam penelitian yaitu serangkaian alat pembuatan brownies dan alat analisis kimia dan biokimia yaitu galas ukur, vortek memmert tipe VM-300, buret, pipet volume, mikro pipet, botol timbang, oven memmert tipe UM-400, labu ukur, beker glass, tabung reaksi, ball pipet spektrofotometer UV-VIS merk Thermo Scientific Tipe Genesys 10SUV-VIS dan peralatan analisis lainnya.

\section{Tahapan Penelitian}

Penelitian ini menggunakan rancangan acak lengkap (RAL), dengan dua faktor yaitu rasio perbandingan tepung koro pedang dan tepung mocaf (30:70, 40:60, 50:50) dan lama pemanganggan $(45,60,75$ menit). Jumlah perlakuan Ada 9 kombinasi dan masingmasing kombinasi diulang sabanyak 2 kali. Data yang diperoleh dianalisis dengan uji sidik ragam jenjang nyata 0,05 , jika ada beda nyata silanjutkan uji tukey untuk mengetahui beda nyata antara perlakuan pada tingkat signifikan 5\%. 


\section{Pembuatan tepung koro pedang}

Biji koro pedang direndam selama 72 jam (3 hari) setiap 6 jam sekali air diganti. Biji koro pedang dikupas kulitnya dan direbus pada suhu $100^{\circ} \mathrm{C}$ selama 60 menit.Biji koro dirajang kecil-kecil untuk memperluas permukaan. Dikeringkan pada suhu $60^{\circ} \mathrm{C}$ selama 7 jam. Ditepungkan dan diayak dengan ukuran 80 meshTepung koro pedang menurut Rachmawanti, Widanti, \& Khairin (2016) dan Gilang, Affandi, \& Ishartani (2013).

\section{Proses pembuatan brownies (Widanti dan Mustofa., 2015)}

Melelahkan coklat blok dan margarin dengan cara waterbath, Telur dan gula di dikocok menggunakan mixer hingga mengembang. Masukkan tepung koro, tepung mocaf, coklat bubuk dan baking powder yang sudah diayak. Dimixer hingga homogen Masukkan ke dalam loyang yang sudah dilumuri dengan margarin. Oven dengan suhu $150^{\circ} \mathrm{C}$ dengan waktu sesuai perlakuan. Dikeluarkan dari oven dan didinginkan Brownies tepung koro substitusi tepung mocaf.

\section{Cara pengumpulan data}

Analisis yang digunakan dalam penelitian ini yaitu kimis, fisika dan organolpatik. Analisis Kimia dan fisika terdiri dari Analisis kadar protein dengan metode Metode Kjeldahl (Sudarmadji et al., 1997), kadar lemak dengan metode shoxlet (AOAC, 1995), kadar air metode thermografimetri (Sudarnadji et al., 1997), Analisis Kadar Abu dengan Metode Pemanasan (Sudarmadji el al, 1989), kadar gula total dengan metode nelson-Somogy (Sudarmadji et al., 1997) dan Uji Organoleptik Meode Scoring Test (Kartika et al., 1998) meliputi uji warna coklat, uji rasa koro pedang, uji rasa mocaf, uji tekstur lembut, uji keseluruhan.

\section{HASIL DAN PEMBAHASAN}

\section{Analisis kimia}

Hasil analisis uji kimia brownies dengan perlakuan perbandingan tepung koro pedang dan tepung mocaf dan lama pemanganggan dapat dilihat pada Tabel 1. Perbandingan tepung koro dan mocaf 30:70 dengan waktu pemanganggan 60 menit merupakan hasil terbaik pada protein dengan nilai $8,73 \%$.

\section{Kadar air}

Hasil analisis sidik ragam menunjukkan bahwa kadar air brownies pada perlakuan substitusi tepung koro-mocaf dan kombinasi perlakuan berbeda tidak nyata $\alpha>0,05)$. kadar air tertinggi pada brownies yaitu $19,30 \%$ diperoleh pada perlakuan perbandingan tepung koro dan tepung mocaf 30:70 dengan lam apemanggangan 45 menit. Sedangkan kadar air paling rendah yaitu $16,14 \%$ diperoleh dari perbandingan tepung koro dan mocaf 50:50 dengan lama pemangggangan 75 menit. Kadar air brownies menurun dengan semakin banyaknya penambahan tepung koro dan semakin rendahnya penambahan tepung mocaf. Semakin lama waktu pemanggangan juga menyebabkan kadar air semakin rendah, disebabkan karena proses pemanganggan yang semakin lama menyebabkan semakin banyaknya air yang menguap.

\section{Kadar air}

Hasil analisis sidik ragam menunjukkan bahwa kadar air brownies pada perlakuan substitusi tepung koro-mocaf dan kombinasi perlakuan berbeda tidak nyata $\alpha>0,05)$. kadar air tertinggi pada brownies yaitu $19,30 \%$ diperoleh pada perlakuan perbandingan tepung koro dan tepung mocaf 30:70 dengan lam apemanggangan 45 menit. Sedangkan kadar air paling rendah yaitu $16,14 \%$ diperoleh dari perbandingan tepung koro dan mocaf 50:50 dengan lama pemangggangan 75 menit. Kadar air brownies menurun dengan semakin banyaknya penambahan tepung koro dan semakin rendahnya penambahan tepung mocaf. Semakin lama waktu pemanggangan juga menyebabkan kadar air semakin rendah, disebabkan karena proses pemanganggan yang semakin lama menyebabkan semakin banyaknya air yang menguap. 
Tabel 1 Rangkuman hasil analisis kimia dan fisika brownies bebas gluten dari tepung koro pedang yang disubstitusi tepung mocaf dengan variasi lama pemangganggan

\begin{tabular}{ccccccc}
\hline $\begin{array}{c}\text { Perbandingan } \\
\text { tepung koro } \\
\text { pedang dan } \\
\text { tepung mocaf }\end{array}$ & $\begin{array}{c}\text { Lama } \\
\text { Pemanganggan }\end{array}$ & $\begin{array}{c}\text { Kadar air } \\
(\%)\end{array}$ & $\begin{array}{c}\text { Kadar Abu } \\
(\%)\end{array}$ & $\begin{array}{c}\text { Lemak } \\
(\%)\end{array}$ & $\begin{array}{c}\text { Gula } \\
\text { Total } \\
(\%)\end{array}$ & $\begin{array}{c}\text { Protein } \\
(\%)\end{array}$ \\
\hline $30: 70$ & 45 menit & $19,30^{\mathrm{a}}$ & $0,06^{\mathrm{a}}$ & $22,11^{\mathrm{bc}}$ & $13,69^{\mathrm{b}}$ & $7,11^{\mathrm{c}}$ \\
& 60 menit & $19,01^{\mathrm{a}}$ & $0,18^{\mathrm{ab}}$ & $22,34^{\mathrm{bcd}}$ & $14,04^{\mathrm{b}}$ & $8,73^{\mathrm{e}}$ \\
& 75 menit & $18,58^{\mathrm{a}}$ & $1,21^{\mathrm{ab}}$ & $21,18^{\mathrm{a}}$ & $6.09^{\mathrm{a}}$ & $7.86^{\mathrm{d}}$ \\
$40: 60$ & 45 menit & $17,80^{\mathrm{a}}$ & $0,34^{\mathrm{ab}}$ & $22,45^{\mathrm{cd}}$ & $11,02^{\mathrm{ab}}$ & $6,60^{\mathrm{b}}$ \\
& 60 menit & $19,19^{\mathrm{a}}$ & $0,96^{\mathrm{ab}}$ & $22,50^{\mathrm{cd}}$ & $13,03^{\mathrm{b}}$ & $7,85^{\mathrm{d}}$ \\
$50: 50$ & 75 menit & $17,69^{\mathrm{a}}$ & $0,49^{\mathrm{ab}}$ & $21,84^{\mathrm{b}}$ & $15,40^{\mathrm{b}}$ & $8,59^{\mathrm{e}}$ \\
& 45 menit & $17,02^{\mathrm{a}}$ & $1,35^{\mathrm{ab}}$ & $22,77^{\mathrm{d}}$ & $5,64^{\mathrm{a}}$ & $7,10^{\mathrm{c}}$ \\
& 60 menit & $17,25^{\mathrm{a}}$ & $1,85^{\mathrm{b}}$ & $23,36^{\mathrm{e}}$ & $15,36^{\mathrm{b}}$ & $6,13^{\mathrm{d}}$ \\
& 75 menit & $16,14^{\mathrm{a}}$ & $1,56^{\mathrm{ab}}$ & $22,23^{\mathrm{bc}}$ & $15,38^{\mathrm{b}}$ & $6,13^{\mathrm{a}}$ \\
\hline
\end{tabular}

Keterangan: Rerata yang diikuti huruf yang berbeda pada kolom yang sama menunjukkan berbeda nyata pada uji tukey tarif signifikan 5\%

\section{Kadar abu}

Hasil analisis sidik ragam menunjukkan bahwa kadar abu brownies pada perlakuan substitusi tepung koro-mocaf, waktu pemangangan dan kombinasi perlakuan keduanya berbeda tidak nyata $(\alpha>0,05)$. Kadar abu tertinggi yaitu $1,85 \%$ diperoleh pada perlakuan perbandingan tepung koro dan tepung mocaf 50:50 dengan lama pemanggangan 60 menit. Sedangkan kadar abu paling rendah yaitu $0,06 \%$ diperoleh dari perbandingan tepung koro dan mocaf 30:70 dengan lama pemanggangan 45 menit. Peningkatan kadar abu pada brownies panggang koro pedang dikarenakan koro pedang memiliki kadar abu lebih tinggi dibandingkan dengan kadar abu tepung mocaf. Kandungan kadar abu dalam suatu produk makanan dipengaruhi oleh mineral dari bahan yang digunakan (Winarno, 2009). Menurut Sunarsi, Marcellius, \& Wahyuni (2011) penurunan kadar abu terjadi dengan penambahan mocaf yang dapat mengakibatkan kandungan abu menjadi semakin rendah, sehingga mempengaruhi penurunan kadar abu yang dihasilkan.

\section{Kadar lemak}

Hasil analisis sidik ragam menunjukkan bahwa kadar lemak brownies pada perlakuan sustitusi tepung koro-mocaf dan pada perlakuan waktu berbeda nyata $(\alpha<0,05)$. Hasil perlakuan perbedaan tepung koro pedang dan tepung mocaf dengan lama pemanganggan menunjukkan berbeda nyata. kadar lemak tertinggi pada brownies yaitu
23,36\% diperoleh pada perlakuan presentasi tepung koro dan tepung mocaf 50:50 dan pada waktu 60 menit. Sedangkan kadar lemak paling rendah yaitu $21,18 \%$ diperoleh dari perbandingan tepung koro dan mocaf 30:70 dan waktu 75 menit. Kadar lemak pada brownies semakin naik dengan adanya penambahan tepung koro, hal ini disebabkan karena tepung koro memiliki kadar lemak 4,19\% (Gilang, Afandi \& Ishari, 2013) dan tepung mocaf $0,83 \%$ (Maulida, 2016).

\section{Kadar gula total}

Hasil analisis sidik ragam menunjukkan bahwa kadar gula total brownies pada perlakuan substitus tepung koro-mocaf dan kombinasi perlakuan berbeda nyata $(\alpha<0,05)$. Sedangkan pada perlakuan waktu pemanganggan berbeda tidak nyata $(\alpha>0,05)$. Kadar gula total tertinggi pada brownies yaitu $15,40 \%$ diperoleh pada perlakuan perbandingan tepung koro dan tepung mocaf 40:60 dengan lama pemanggangan 75 menit. Kadar gula total paling rendah yaitu $11,02 \%$ diperoleh dari perbandingan tepung koro dan mocaf 40:60 dengan lama pemanggangan 45 menit. Semakin banyak penggunaan tepung koro pedang, menghasilkan brownies dengan kadar gula total yang semakin tinggi. Kadar gula juga dipengaruhi oleh lama pemanggangan yaitu semakin lama waktu pemanggangan, kadar gula semakin tinggi.

\section{Kadar protein}

Hasil analisis sidik ragam menunjukkan bahwa kadar protein brownies pada 
perlakuan substitusi tepung koro-mocaf, waktu pemanggangan dan kombinasi perlakuan keduanya berbeda nyata $(\alpha<0,05)$. kadar protein tertinggi pada brownies yaitu $8,73 \%$ diperoleh pada perlakuan prosentase tepung koro dan tepung mocaf 30:70 dan pada waktu 60 menit. Sedangkan kadar protien paling rendah yaitu $6,13 \%$ diperoleh dari perbandingan tepung koro dan mocaf 50:50 dan waktu 45 dan 75 menit. Menurut Serbranek (2009), kandungan protein yang terukur tergantung pada jumlah bahan yang ditambahkan dan sebagian besar dipengaruhi oleh kandungan air. Menurut Dian (2015) penggunaan suhu yang terlalu tinggi dan semakin lama pemanganggan akan mengakibatkan penurunan kadar protein. Suhu dan lama pemanggangan akan terjadi denaturasi protein yang mengakibatkan perubahan struktur protein. Denaturasi protein adalah suatu kejadian di mana protein mengalami perubahan atau perusakan struktur sekunder, tersier dan kuartenernya (Zulfikar, 2008).

\section{Uji Sensoris}

\section{Warna}

Warna merupakan salah satu faktor yang menentukan mutu dan secara visual warna tampil lebih dahulu dan kadangkadang sangat menentukan, sehingga warna dijadikan atribut organoleptik yang penting dalam suatu bahan pangan (Winarno, 2004). Hasil analisis sidik ragam menunjukkan bahwa warna brownies pada perlakuan subtitusi tepung koro-mocaf dan kombinasi perlakuan keduannya berbeda tidak nyata $(\alpha>0,05)$. Sedangkan pada perbedaan waktu pemanganggan berbeda nyata $(\alpha<0,05)$. penilaian panelis terhadap brownies tepung koro pedang dan tepung mocaf tertinggi diperoleh dari presentasi tepung koro pedang dan tepung terigu 50:50 dan pada waktu 75 menit yang memiliki warna paling coklat dengan nilai 3,34 sedangkan warna yang paling coklat muda yaitu pada konsentrasi tepung koro pedang dan tepung mocaf 30:70 pada waktu 75 menit yaitu sebesar 2,64. Dari penilaian panelis dapat disimpulkan bahwa warna coklat pada brownies dihasilkan dari perbandinggan tepung koro yang semakin banyak dan lama pemanggangan semakin lama. Semakin tinggi kandungan protein maka reaksi maillard juga semakin intensif dan warna brownies semakin gelap.

Tabel 2 Rangkuman hasil analisis sensoris brownies bebas gluten dari tepung koro pedang yang disubstitusi tepung mocaf dengan variasi lama pemangganggan

\begin{tabular}{ccccccc}
\hline $\begin{array}{c}\text { Perbandingan } \\
\text { tepung koro } \\
\text { pedang dan } \\
\text { tepung mocaf }\end{array}$ & $\begin{array}{c}\text { Lama } \\
\text { Pemanganggan }\end{array}$ & Warna & $\begin{array}{c}\text { Rasa } \\
\text { koro } \\
\text { pedang }\end{array}$ & $\begin{array}{c}\text { Rasa } \\
\text { mocaf }\end{array}$ & $\begin{array}{c}\text { Tekstur } \\
\text { lembut }\end{array}$ & $\begin{array}{c}\text { Kesukaan } \\
\text { keseluruhan }\end{array}$ \\
\hline $30: 70$ & 45 menit & $2,71^{\mathrm{a}}$ & $3,10^{\mathrm{a}}$ & $3,12^{\mathrm{a}}$ & $2,92^{\mathrm{a}}$ & $3,05^{\mathrm{a}}$ \\
& 60 menit & $2,95^{\mathrm{a}}$ & $3,13^{\mathrm{a}}$ & $3,21^{\mathrm{a}}$ & $2,80^{\mathrm{a}}$ & $3,11^{\mathrm{a}}$ \\
$40: 60$ & 75 menit & $2,64^{\mathrm{a}}$ & $2,94^{\mathrm{a}}$ & $3,20^{\mathrm{a}}$ & $2,97^{\mathrm{a}}$ & $3,06^{\mathrm{a}}$ \\
& 45 menit & $3,07^{\mathrm{a}}$ & $2,92^{\mathrm{a}}$ & $2,94^{\mathrm{a}}$ & $2,61^{\mathrm{a}}$ & $2,95^{\mathrm{a}}$ \\
& 60 menit & $3,11^{\mathrm{a}}$ & $3,22^{\mathrm{a}}$ & $3,05^{\mathrm{a}}$ & $2,64^{\mathrm{a}}$ & $2,89^{\mathrm{a}}$ \\
$50: 50$ & 75 menit & $3,23^{\mathrm{a}}$ & $2,96^{\mathrm{a}}$ & $3,28^{\mathrm{a}}$ & $2,54^{\mathrm{a}}$ & $2,93^{\mathrm{a}}$ \\
& 45 menit & $3,17^{\mathrm{a}}$ & $2,85^{\mathrm{a}}$ & $3,04^{\mathrm{a}}$ & $2,92^{\mathrm{a}}$ & $3,21^{\mathrm{a}}$ \\
& 60 menit & $3,21^{\mathrm{a}}$ & $3,10^{\mathrm{a}}$ & $3,01^{\mathrm{a}}$ & $2,61^{\mathrm{a}}$ & $2,85^{\mathrm{a}}$ \\
& 75 menit & $3,34^{\mathrm{a}}$ & $3,19^{\mathrm{a}}$ & $3,41^{\mathrm{a}}$ & $2,61^{\mathrm{a}}$ & $2,99^{\mathrm{a}}$ \\
\hline
\end{tabular}

Keterangan :

- Warna : semakin tinggi angka menunjukkna warna yang lebih coklat.

- Rasa koro pedang : semakin tinggi angka menunjukkan rasa koro semakin terasa.

- Rasa mocaf : semakin tinggi angka menunjukkan rasa mocaf semakin terasa.

- Tekstur lembut : semakin tinggi angka menunjukkan semakin lembut.

- Kesukaan keseluruhan : semakintinggi angka menunjukkan semakin disukai. 


\section{Rasa tepung koro pedang}

Hasil analisis sidik ragam menunjukkan bahwa rasa tepung koro pedang brownies pada perlakuan substitusi tepung koro-mocaf, waktu pemanganggan dan kombinasi perlakuan keduanya berbeda tidak nyata $(\alpha>0,05)$. penilaian panelis mengenai rasa tepung koro pedang paing tinggi diperoleh dari perlakuan konsentrasi tepung 40:60 dan waktu pemanggangan 60 menit yang memiliki nilai 3,22 , sedangankan rasa tepung koro pedang yang aromanya paling sedikit atau lebih rendah diperoleh dari konsentrasi tepung koro pedang dan mocaf 50:50 dan lama pemanggangan 45 menit memiliki nilai 2,85 . Dari hasil penilaian panelis rasa tepung koro pedang semakin terasa apabila waktu pemanggan brownies semakin lama. Semakin banyak penambahan tepung koro pedang dalam brownies panggang. Hal tersebut dikarenakan koro memiliki rasa yang khas dan bau langu, namun rasa yang khas tersebut dapat ditutupi oleh rasa manis coklat dan gurih karena adanya penambahan chocolate dark compound dan margarin yang jumlahnya cukup banyak, sehingga rasa brownies relatif sama tetapi juga masih bisa dibedakan menurut Rachmawanti Ridwan, \& Khairini (2016).

\section{Rasa mocaf}

Hasil analisis sidik ragam menunjukkan bahwa rasa tepung mocaf brownies pada perlakuan substitusi tepung koro-mocaf, waktu pemanganggan dan kombinasi perlakuan keduannya berbeda tidak nyata $(\alpha>0,05)$. Penilaian panelis terhadap rasa mocaf pada brownies paling tinggi diperoleh dari perbandingan tepung koro pedang dan tepung mocaf 50:50 dengan lama pemanggangan 75 menit yaitu memiliki nilai 3,41 . Sedangkan untuk rasa mocaf paling rendah diperoleh pada konsentrasi tepung koro pedang dan tepung mocaf 40:60 dengan lama waktu pemanganggan 45 menit yaitu dengan nilai 2,94 .

\section{Tekstur lembut}

Hasil analisis sidik ragam menunjukkan bahwa tekstur lembut brownies pada perlakuan substitusi tepung koro-mocaf, waktu pemanganggan dan kombinasi perlakuan keduannya berbeda tidak nyata $(\alpha>0,05)$. penilaian panelis mengenai tekstur lembut pada brownies nilai paling tinggi 2,97 diperoleh dari perlakuan tepung koro dan tepung mocaf 30:70 dan dengan lama pemanggangan 75 menit, sedangkan panelis terendah adalah 2,54 diperoleh dari perlakuan tepung koro dan tepung mocaf 40:60 dan dengan lama pemanggangan 75 menit. Penambahan tepung koro pedang dapat menurunkan tingkat tektstur pada brownies. Sesuai dalam pembahasan analisa tekstur semakin banyak penambahan tepung koro pedang maka tektur brownies akan semakin keras, dan sifat tepung koro sendiri yang sulit untuk menyatu, sehingga tingkat tektur lembut semakin menurun Rachmawanti, Ridwan, \& Khairini (2016).

\section{Kesukaan keseluruhan}

Hasil analisis sidik ragam menunjukkan bahwa kesukaan keseluruhan brownies pada perlakuan substitusi tepung koro-mocaf, waktu pemangangan d kombinasi perlakuan keduannya berbeda tidak nyata $(\alpha>0,05)$. tingkat kesukaan keseluruhan tertinggi dengan nilai 3,21 deperoleh dari perlakuan presentase tepung koro dan tepung mocaf 50:50 dengan lama pemanggangan 45 menit, sedangkan penilaian panelis yang terendah adalah 2,89 diperoleh dari perlakuan substitusi tepung koro dan tepung mocaf 40:60 dan dengan lama pemanganggan 60 menit. Kesukaan keseluruhan panelis tertinggi pada formulasi tepung koro dan tepung mocaf 50:50, tetapi kesukaan yang hampir sama panelis menyukai formulasi brownies yang tidak terlalu banyak mengandung tepung koro hal ini disebabkan tepung koro yang memiliki tekstur lebih kasar dan bau langu. Sedangan penambahan tepung koro yang lebih sedikit memiliki tekstur yang lebih halus dan aroma langgu tidak begitu terasa.

\section{KESIMPULAN}

Brownies yang paling disukai konsumen adalah brownies dengan perlakuan konsentrasi tepung koro pedang dan tepung mocaf 30:70 dengan lama pemanggangan 60 menit yang memiliki karakteristik kimia kadar air 19,01\%, kadar abu 0,18\%, kadar lemak 22,34\%, kadar gula total $18,04 \%$ dan 
kadar protein $8,73 \%$. Uji organolaptik terhadap warna coklat 2,95 , rasa koro pedang 3,13 , rasa mocaf 3,21 , tekstur lembut 2.80 dan kesukaan keseluruhan 3,11. Kadar protein pada perlakuan ini juga merupakan kadar protein tertinggi di antara perlakkuan lainnya.

\section{DAFTAR PUSTAKA}

Assotion Of Analytical Communities. (1995). Official methods of analysis. $16^{\text {th }}$ ed. Washington D.C:AOAC Int.

Dian, S., Almasyhuri \& Lamid, A. (2015). Pengaruh proses pemasakan terhadap komposisi zat gizi bahan pangan sumber protein. Pusat Biomedis dan Teknologi Dasar Kesehatan, 25 (4), 235-242.

Gilang, R., Afandi, D.R. \& Ishari, D. (2013). Karakteristik fisik dan kimia tepung koro pedang (canavalia ensiformis) dengan variasi perlakuan pendahuluan. Jurnal Teknosains, 2(3), 2302-0733.

Kartika, B. D., Hastuti , W \& Supratno. (1998). Pedoman uji indrawi bahan pangan. Yogyakarta: PAU Pangan Dan Gizi Universitas Gajah Mada.

Kasmidjo, R. B. (1990). Tempe: Mikrobiologi dan biokimia pengolahan serta pemanfaatannya. Yogyakarta: Pusat Antar Universitas Pangan Dan Gizi UGM.

Maulida, M. H. (2016). Pengaruh penambahan pure daun kelor dan bubuk daun kelor terhadap hasil jadi mie kering mocaf (Skripsi). Universitas Negeri Surabaya, Surabaya.

Pambayun, R., \& Martini, H. (2000). Detoksifikasi HCN pada pengolahan kripik gadung dengan berbagai metodis dan lama pemanasan (Prosiding Seminar Nasional Makanan Tradisional). Malang.

Rachmawanti, A. D., Ridwan, A. A., \& Khairini, R. S. (2016). Pengaruh penambahan tepung koro pedang (Canavalia ensiformis) termodifikasi sebagai substitusi tepung terigu terhadap karakteristik kimia, fisik dan sensori brownies panggang. Jurnal Teknosains Pangan, 5(1), 2302-0733.

Salim, M. (2011). Mengolah singkong manjadi tepung mocaf. Yogyakarta: Lily Publisher.

Serbranek, J. (2009). Basic curing ingredients. Didalam Terte R. Editor. Ingredients in meat product. properties, functionality and applications. New York: Springer Science.

Subagio, A. (2007). Indurtialisasi modified canava flour (mocaf) sebagai bahan baku industri pangan untuk menunjang diversifikasi pangan pokok nasional. Jember: Fakultas Teknologi Pertanian Universitas Jember.

Sudarmadji S, Haryono B., \& Suhardi. (1997). Prosedur analisis untuk bahan makanan dan pertanian. Yogyakarta: Universitas Gajah Mada.

Sudarmadji, S., Haryono, B., \& Suhardi. (1989). Prosedur analisis untuk bahan makanan dan pertanian. Yogyakarta: Universitas Gajah Mada.

Sunarsi, S., Marcellius, S. A., Wahyuni, A., \& Ratnaningsih, W. (2011). Manfaat singkong menjadi tepung mocaf untuk pemberdayaan masyarakat Sumberejo (Seminar hasil penelitian dan pengabdian kepada masyarakat masyarakat). Universitas Bantara Sukoharjo.

Tempo. (2013). Indonesia didesak kurangi impor gandum. Diakses:Http://Www.Tempo.Co/Read/ News/2013/07/24/090499391/Indonesia -Didesak-Kurangi-Impor-Gandum.

Widanti, Y.A. \& Mustofa, A. (2015). Karakteristik organoleptik brownies dengan campuran tepung mocaf dan tepung ketan hitam dengan variasi lama pemangangan. Jurnal Joglo, 27(2), 272-280.

Winarno, F.G. (2004). Kimia pangan dan gizi. Jakarta: PT. Gramedia pustaka utama. 
Winarno, F.G. (2009). Kimia pangan dan gizi. Jakarta: Gedia Pustaka Utama.

Windrati, W. S. A ., Nalf \& Agustine. P. D. (2010). Sifaf fungsional Protein Rich Flour (PRF) koro pedang (Canavalia ensiformis L). Jember: Argotek, 4(1).

Zulfikar. (2008). Kimia kesehatan Jilid 3. Jakarta: Departemen Pendidikan Nasional. ISBN.978-602-8320-48-1. 